\title{
MICROSTRUCTURE EVOLUTION AND PROPERTY CHANGES OF Al-Si-Cu ALLOY BY CONTROLLING DIRECTIONAL SOLIDIFICATION PARAMETERS
}

\author{
RAZVOJ MIKROSTRUKTURE IN SPREMEMBA LASTNOSTI \\ ZLITINE Al-Si-Cu S KONTROLIRANJEM PARAMETROV \\ DIREKTNEGA STRJEVANJA
}

\author{
Xiaojie Yi' ${ }^{1}$, Tao He ${ }^{1, *}$, Yuanming Huo ${ }^{1}$, Shoushuang Chen², Yajun $\mathrm{Xu}^{1}$, \\ Abdou Yahouza Mahamane Sani ${ }^{1}$ \\ ${ }^{1}$ School of Mechanical and Automotive Engineering, Shanghai University of Engineering Science, no. 333 Longteng Road, \\ Shanghai 201620, China \\ ${ }^{2}$ Chinese Academy of Social Sciences, Institute of Quantitative \& Technical Economics, 5 Jianguomennei Street, Beijing 100732, China
}

Prejem rokopisa - received: 2019-03-09; sprejem za objavo - accepted for publication: 2019-04-24

doi:10.17222/mit.2019.051

\begin{abstract}
As the properties of the Al-Si-Cu alloy depend on the microstructure, it is necessary to study the effects of processing parameters on the microstructure to control the properties of the Al-Si-Cu alloy. A novel Al-Si-Cu alloy rod was prepared using directional solidification (DS) of liquid metal cooling and the Al-Si-Cu alloy rod was investigated by using a scanning electron microscope (SEM), a JVJ-50s test machine, a MHVD-1000IS microhardness tester and a FT300 resistivity tester. The SEM was used to capture micrographs. The JVJ-50s test machine was employed to measure stress-strain relationships. The MHVD-1000IS microhardness tester was used to measure the microhardness of the specimens. The FT300 resistivity tester was used to evaluate the electrical conductivity. Experimental results indicate that the dendrite structure of the microstructure can be refined by increasing the melting temperatures during DS, but the exorbitant temperature would make the precipitated phase coarsen. It was found that when the melting temperature was $750{ }^{\circ} \mathrm{C}$ and the pulling rate was $300 \mu \mathrm{m} \cdot \mathrm{s}^{-1}$, the maximum tension strength and microhardness were $232 \mathrm{MPa}$ and $102 \mathrm{HV}$, respectively. Moreover, when the vacuum was $0.4 \times 10^{-3} \mathrm{MPa}$, the electrical properties of the alloy are the best, i.e., the minimum resistivity was $17.6 \mu \Omega \cdot \mathrm{mm}$. Therefore, a set of optimum processing parameters, i.e., the melting temperature of $750{ }^{\circ} \mathrm{C}$, the pulling rate of $300 \mu \mathrm{m} \cdot \mathrm{s}^{-1}$ and the vacuum of $0.4 \times 10^{-3} \mathrm{MPa}$, can be selected to improve the microstructure and properties of the Al-Si-Cu alloy.
\end{abstract}

Keywords: directional solidification, Al-Si-Cu alloy, microstructure, mechanical properties, electrical resistivity

Lastnosti Al-Si-Cu zlitin so močno odvisne od mikrostrukture. Zato je za nadzor njihovih lastnosti potrebno raziskati učinek procesnih parametrov na formiranje njihove mikrostrukture. Avtorji so sintetizirali novo zlitino na osnovi Al-Si-Cu s postopkom direktnega strjevanja (DS) raztaljene kovine. Ohlajene palice zlitine Al-Si-Cu izbrane kemijske sestave so preiskovali s pomočjo metalografskih metod z uporabo vrstičnega elektronskega mikroskopa (SEM), trgalnega stroja JVJ-50s, merilnika mikrotrdote MHVD-1000IS, in merilnika električne upornosti FT300. SEM so uporabili za izdelavo metalografskih posnetkov. S pomočjo JVJ-50s stroja so izdelali krivulje odvisnosti med napetostjo in deformacijo. Z merilnikom mikrotrdote MHVD-1000IS so določili mikrotrdoto vzorcev sintetizirane zlitine. Z merilnikom FT300 pa so določili njihovo električno upornost. Eksperimentalni rezultati preiskav so pokazali, da je dendritno mikrostrukturo možno rafinirati (udrobiti) z višanjem temperature pregretja nad tališče zlitine med DS. Toda pretirano poviševanje temperature pregretja lahko vodi do nastanka grobih izločkov sekundarne faze. Avtorji ugotavljajo, da so pri temperaturi pregretja $750{ }^{\circ} \mathrm{C}$ in hitrosti vlečenja strjene palice iz taline $300 \mu \mathrm{m} \cdot \mathrm{s}^{-1}$, dosegli maksimalno natezno trdnost $232 \mathrm{MPa}$ in mikrotrdoto zlitine $102 \mathrm{HV}$. Nadalje ugotavljajo, da so pri vakuumiranju na podtlak 0,4 $\times 10^{-3} \mathrm{MPa}$ dosegli najboljše električne lastnosti zlitine z najmanjšo električno upornostjo $17,6 \mu \Omega \cdot \mathrm{mm}$. Tako so določili skupino optimalnih procesnih parametrov, in sicer temperaturo pregretja pri $750{ }^{\circ} \mathrm{C}$, hitrosti vlečenja $300 \mu \mathrm{m} \cdot \mathrm{s}^{-1}$ in vakuum 0,4 $\times 10^{-3} \mathrm{MPa}$. Na ta način so lahko izboljšali mikrostrukturo in lastnosti izbrane Al-Si-Cu zlitine.

Ključne besede: direktno strjevanje, zlitina Al-Si-Cu, mikrostruktura, mehanske lastnosti, električna upornost

\section{INTRODUCTION}

Aluminum alloys are widely used in the fields of aerospace, ships and automobiles. ${ }^{1}$ The Al-Si-Cu alloy is one of the most popular cast aluminum alloys, which not only has good casting properties, but also has the advantages of low density, good corrosion resistance, small linear expansion coefficient, high strength and microhardness, good wear resistance and heat resistance, etc. ${ }^{2,3}$ However, with the development of advanced manufactur-

*Corresponding author's e-mail

hetao@sues.edu.cn ing technology, the comprehensive mechanical properties of $\mathrm{Al}-\mathrm{Si}-\mathrm{Cu}$ alloys need to be further improved to meet the requirements of modern mechanical structures.

A lot of research has been done on improving the properties of Al-Si-Cu alloys. Similarly, some publications focused on the improvement of properties of $\mathrm{Al}-\mathrm{Si}-\mathrm{Cu}$ alloys by adding $\mathrm{Mg},{ }^{4}$ rare-earth elements ${ }^{5}$ and trace elements and changing the heat-treatment process and different casting forming processes includes squeeze casting, semi-solid forming, ${ }^{6}$ lost foam casting ${ }^{7}$ and vacuum die casting, ${ }^{8}$ etc. 
The directional solidification (DS) technique used in this work is a new casting process that controls the unidirectional heat flow through specific temperature gradients to achieve the desired orientation of the tissue and high-performance materials. ${ }^{9}$ Especially in the study of changing the performance of aluminum-based alloys, ${ }^{10,11}$ it has been rapidly developed since its birth. Y. J. Sun et al. ${ }^{12}$ studied the effect of directional solidification on the microstructure and properties of pure aluminum; the results show that the directional solidification can improve the electrical resistivity of the aluminum rods compared with the ordinary casting process. G. Wan et al. ${ }^{13}$ studied the effects of current treatment on the DS of the Al-Si alloy, the results show that the directional solidification is the most obvious at the pulling rates of $3 \mathrm{~mm} / \mathrm{min}$. K. Q. Sun et al..$^{14}$ studied the effect of melt overheating on the microstructure and properties of the DS of the $\mathrm{Al}-\mathrm{Cu}$ alloy. The results show that the strength of the alloy increases by nearly $60 \%$ and the elongation nearly doubled after the melt overheat treatment. L. H. Cui et al. ${ }^{15}$ studied the effects of $\mathrm{Cu}$ content on the DS of $\mathrm{Al}-\mathrm{Cu}$ alloy; it was found that when the content of $\mathrm{Cu}$ increased from $1.77 \%$ to $3.00 \%$, the spacing of primary dendrite increased gradually, but the increase of dendrite spacing was small. N. C. Si et al. ${ }^{16}$ studied the effects of the temperature gradient on the primary dendrite spacing of the directionally solidified Al-4.5\% Cu alloy. The results show that when the other solidification parameters are unchanged, with the increase of temperature gradient, the primary dendrites become smaller and smaller, straight, basically parallel distribution. It can be seen that the research on the DS of Al-base alloys is mainly focused on the study of alloy properties by changing the chemical composition of the alloy, the processing method and changing a single processing parameter. However, few researches focus on the comprehensive effect of multiple processing parameters on the micro- structure and properties of the DS Al-based alloys. Furthermore, the electrical resistivity of Al-based alloys has no related studies.

Therefore, the aim of this work was to investigate the effects of three processing parameters, i.e., the melting temperatures, the pulling rates and the vacuum, on the microstructure, mechanical properties and electrical resistivity of the Al-Si-Cu alloy under DS conditions. Based on the above objectives, we have done the following work: firstly, Al-Si-Cu alloy rods are prepared using DS under different process parameters. Secondly, a scanning electron microscope (SEM), JVJ-50s test machine, MHVD-1000IS microhardness tester and FT300 resistivity tester are used to measure the microstructure, mechanical properties and electrical resistivity. Finally, the correlation between the processing parameters and the microstructure and the properties are discussed to determine the optimum range of processing parameters.

\section{MATERIALS AND METHODS}

\subsection{Specimens prepared by directional solidification}

The DS experiment was carried out in high-vacuum DS equipment, as shown in Figure 1a. The schematic diagram of the directional solidification system is shown in Figure 1b. DS equipment mainly consists of two parts: the electric arc melting function and the directional solidification function. The raw materials chemical composition consists of $99.99 \% \mathrm{Al}, 99.95 \% \mathrm{Si}$ and $99.99 \%$ $\mathrm{Cu}$, etc., shown in Table 1. The raw material particles polished surface clean, put acetone in the surface with ultrasonic shocks out of the stain. Arc melting was carried out to ensure that the alloy was fully melted and mixed evenly. During the smelting process, electromagnetic stirring was applied and reversed repeatedly for more than five times to obtain the experimental speci-
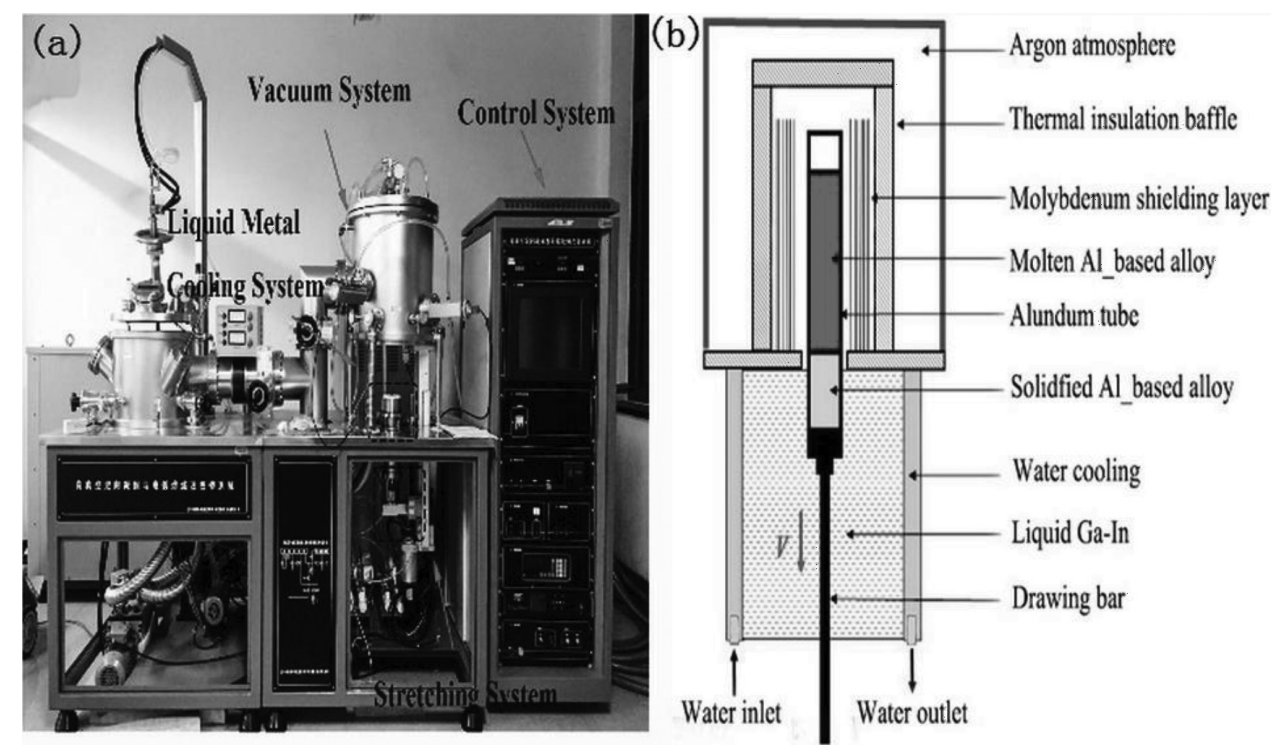

Figure 1: a) directional solidification equipment, b) schematic diagram of directional solidification system $^{18}$ 
mens. Wire cutting equipment was used to take out the rod with a diameter of $10 \mathrm{~mm} \times 150 \mathrm{~mm}$ as the DS specimen.

The DS experiment was carried out using three stages: the heating stage, the insulation stage and the pulling stage. 1) The heating stage: the alloy test rods were placed in a crucible with an inner diameter of 10 $\mathrm{mm}$ in the DS equipment. The crucible was an $\mathrm{Al}_{2} \mathrm{O}_{3}$ corundum tube with a purity of $99.9 \%$. 2) The furnace of the DS equipment was pumped to a high vaccum using a mechanical pump and a molecular pump. 3) The heating furnace was filled with high-purity argon gas. The alloy rod was heated and melted by resistance heating in a non-pollution environment. To prevent the consumption of alloy elements from evaporation, when the temperature of the test rod reaches the set temperature by the thermocouple, stop heating and begin to enter the insulation stage, which lasts for $5 \mathrm{~min}$. 4) The smelten alloy rod was pulled into the Ga-In alloy solution with a certain pulling rate, when the alloy was cooled to ordinary temperature, the DS experiment was completed. The DS specimens were obtained, as shown in Figure 2. 5) The DS specimens were heat treated in a SX2-5-12N box resistance furnace following the T6 temper, which comprised solution heat treatment at $540{ }^{\circ} \mathrm{C}$ for $8 \mathrm{~h}$, followed by quenching in $60{ }^{\circ} \mathrm{C}$ water. The specimens were then aged at room temperature for $24 \mathrm{~h}$, followed by artificial aging at $155^{\circ} \mathrm{C}$ for $5 \mathrm{~h}$, then air cooled. ${ }^{17}$

Table 1: Al-Si-Cu alloy chemical composition (w/\%)

\begin{tabular}{|c|c|c|c|c|c|}
\hline $\mathrm{Al}$ & $\mathrm{Si}$ & $\mathrm{Cu}$ & $\mathrm{Fe}$ & $\mathrm{Mn}$ & $\mathrm{Zn}$ \\
\hline$\geq 87.7$ & 7 & 4 & $\leq 0.5$ & $\leq 0.5$ & $\leq 0.3$ \\
\hline
\end{tabular}

In DS experiment, different DS specimens were prepared by changing the processing parameters. The melting temperatures varied from $700{ }^{\circ} \mathrm{C}$ to $800{ }^{\circ} \mathrm{C}$. The pulling rates varied from $50 \mu \mathrm{m} \cdot \mathrm{s}^{-1}$ to $300 \mu \mathrm{m} \cdot \mathrm{s}^{-1}$, and the vacuum degree of smelting changes in the range of $4 \times 10^{-4} \mathrm{MPa}$ to $1.2 \times 10^{-3} \mathrm{MPa}$, shown in Table 2 .

\subsection{Mechanical properties test of specimens}

Figure 3 shows the standard plate-shaped tension specimen. Tensile tests were conducted following the ASTM: E8M standard. The mechanical properties were

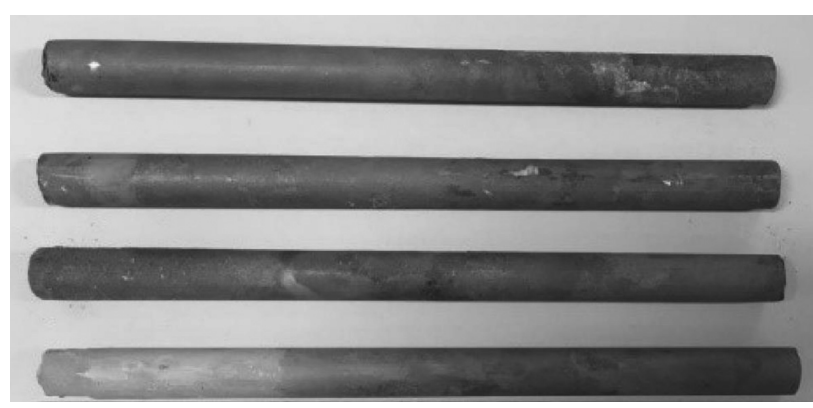

Figure 2: Directional solidification specimens
Table 2: Processing parameters of directionally solidified Al-Si-Cu alloy

\begin{tabular}{|c|c|c|c|}
\hline $\begin{array}{c}\text { Experiment } \\
\text { number }\end{array}$ & $\begin{array}{c}\text { Smelting tem- } \\
\text { perature }\left({ }^{\circ} \mathrm{C}\right)\end{array}$ & $\begin{array}{c}\text { Pulling rates } \\
\left(\mu \mathrm{m} \cdot \mathrm{s}^{-1}\right)\end{array}$ & $\begin{array}{c}\text { Vacuum } \\
\left(\times 10^{-3} \mathrm{MPa}\right)\end{array}$ \\
\hline 1 & 700 & 50 & 0.8 \\
\hline 2 & 700 & 100 & 0.8 \\
\hline 3 & 700 & 200 & 0.8 \\
\hline 4 & 700 & 300 & 0.8 \\
\hline 5 & 750 & 50 & 0.4 \\
\hline 6 & 750 & 50 & 0.8 \\
\hline 7 & 750 & 50 & 1.2 \\
\hline 8 & 750 & 100 & 0.8 \\
\hline 9 & 750 & 200 & 0.8 \\
\hline 10 & 750 & 300 & 0.8 \\
\hline 11 & 800 & 50 & 0.8 \\
\hline 12 & 800 & 100 & 0.8 \\
\hline 13 & 800 & 200 & 0.8 \\
\hline 14 & 800 & 300 & 0.8 \\
\hline
\end{tabular}

measured using the JVJ-50s tension machine at room temperature. The tension speed of the specimens was $1 \mathrm{~mm} \cdot \mathrm{min}^{-1}$.

The microhardness of the transverse section was measured by the MHVD-1000IS microhardness tester. Specimens were polished with the abrasive paper of \#800 to \#2000, cleaned and blown dry with a hair dryer, then placed on a microhardness tester with a set load of $200 \mathrm{~N}$, maintaining the load for $3 \mathrm{~s}$. The microhardness of 7 points was measured, a point was measured 10 times and the average value being obtained.

\subsection{Electrical properties test of specimens}

The specimen with a size of $10 \mathrm{~mm} \times 15 \mathrm{~mm}$ was cut by the DK7632-type linear cutting machine. The surface of the specimen was polished by using water and alcohol to ensure that the surface was smooth and bright. The resistivity of the specimens was tested by using the four-terminal measuring method with an FT300 resistivity tester. (a)
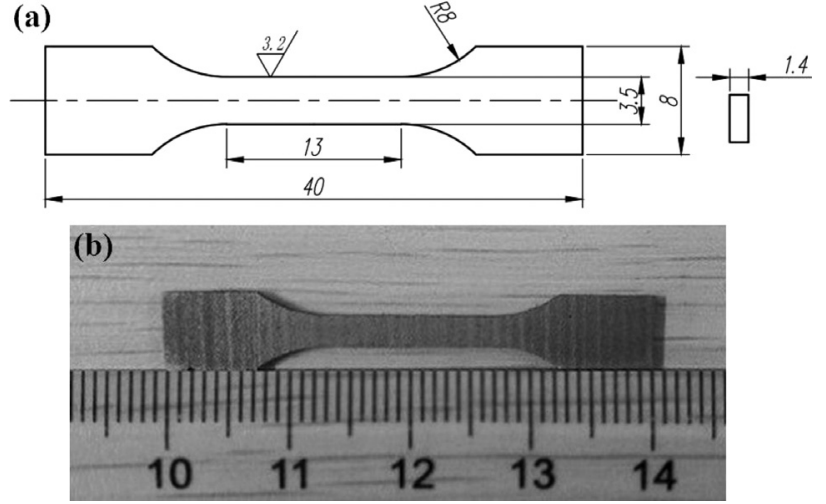

Figure 3: Tension specimens 


\subsection{Microstructure observation of specimens}

Observation specimens were prepared with a size of $2 \mathrm{~mm} \times 2 \mathrm{~mm} \times 2 \mathrm{~mm}$ using a linear cutting machine. Grinding and polishing were performed using the machine. Specimens were etched within a solution of $0.5 \%$ HF with $10 \mathrm{~s}$, and then were washed with water and alcohol. Finally, blown dry with a blower. The microstructures of the specimens were captured by SEM.

\section{RESULTS AND DISCUSSION}

\subsection{Microstructure analysis}

Figure 4 shows the microstructure of the $\mathrm{Al}-\mathrm{Si}-\mathrm{Cu}$ alloy at different melting temperatures of (700, 750 and
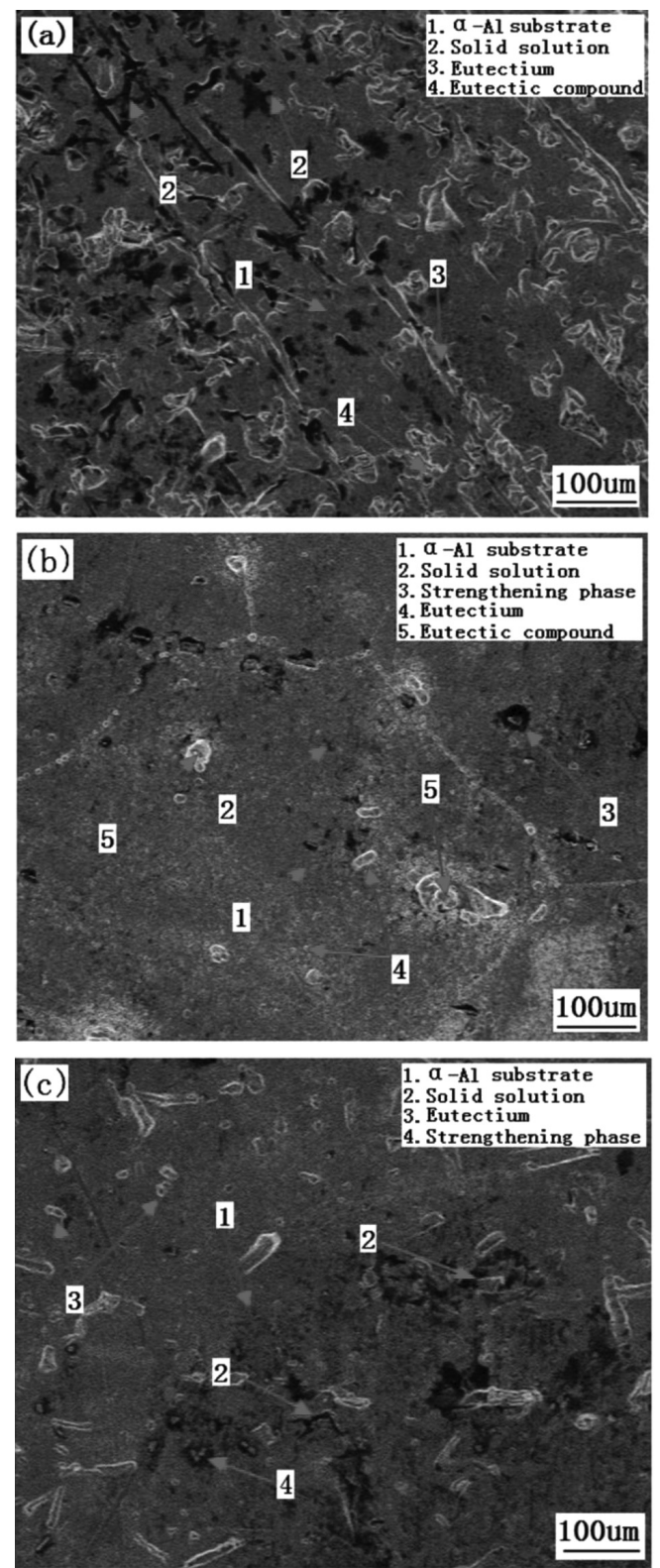

Figure 4: Microstructure of Al-Si-Cu alloy at different melting temperatures with: a) $700{ }^{\circ} \mathrm{C}$, b) $750{ }^{\circ} \mathrm{C}$ and c) $800{ }^{\circ} \mathrm{C}$
800) ${ }^{\circ} \mathrm{C}$ under the pulling rates of $100 \mu \mathrm{m} \cdot \mathrm{s}^{-1}$ at vacuum degree of $8 \times 10^{-4} \mathrm{MPa}$. It can be seen from Figure 4a that the solid-solution dendrites are coarse at $700{ }^{\circ} \mathrm{C}$, which are irregularly distributed in the $\alpha$-Al matrix. And, there are many eutectics and some disk-shaped eutectic compounds in Figure 4a. The grain boundaries can be clearly seen from Figure $\mathbf{4 b}$, and a large number of fine second-phase granular eutectics and strengthening phases are dispersed and precipitated in the vicinity of grain boundaries. The solid-solution dendrites are further refined compared with Figure 4a. At the same time, a small amount of disk eutectic compounds was distributed. It can be seen from Figure $\mathbf{4} \mathbf{c}$ that the melting grain boundary disappeared. A large number of short rod-shaped eutectics were found around the matrix,
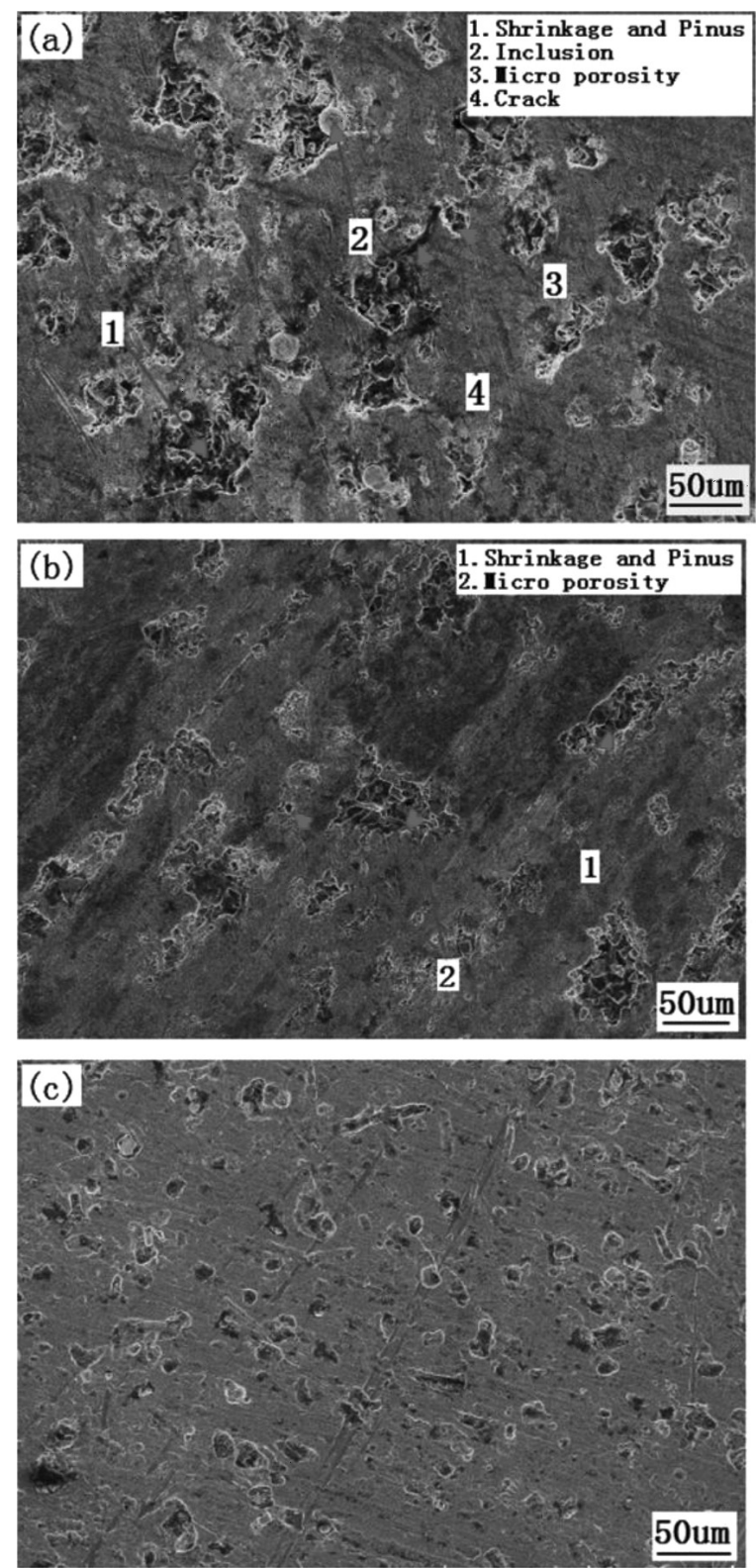

Figure 5: Microstructure of Al-Si-Cu alloy at different degree of vacuum with: a) $1.2 \times 10^{-3} \mathrm{MPa}$, b) $8 \times 10^{-4} \mathrm{MPa}$ and c) $4 \times 10^{-4} \mathrm{MPa}$ 
which are unevenly distributed and also produced a small amount of strip-shaped and plate-shaped eutectics.

Figure 5 shows the effect of the vacuum degree on the microstructure of the $\mathrm{Al}-\mathrm{Si}-\mathrm{Cu}$ alloy under a certain melting temperature of $750{ }^{\circ} \mathrm{C}$ and pulling rate of 50 $\mu \mathrm{m} \cdot \mathrm{s}^{-1}$. It can be seen from Figure 5a that there are more defects, shrinkage and pinus more defects when the vacuum degree is $8 \times 10^{-4} \mathrm{MPa}$, the defects of alloy microstructure are obviously reduced, shown in Figure $\mathbf{5 b}$. The size and number of shrinkage pinus are obviously reduced, and a few areas of micro porosity are produced. Figure 5c shows that, the alloy evenly organized and the densification effect of the alloy is remarkable, and no obvious defects of the microstructure are produced when the vacuum degree is $4 \times 10^{-4} \mathrm{MPa}$.

\subsection{Effect of the melting temperatures and pulling rates on the mechanical properties and electrical properties of $\mathrm{Al}-\mathrm{Si}-\mathrm{Cu}$ alloy}

Figure 6 shows the effect of the melting temperatures and pulling rates on mechanical properties and electrical properties of $\mathrm{Al}-\mathrm{Si}-\mathrm{Cu}$ alloy. It can be seen from Figure 6a that the tension strength of the directional solidification alloy first increases and then decreases with the increase of the melting temperatures. When the melting temperature was $750{ }^{\circ} \mathrm{C}$, the maximum tension strength was $232 \mathrm{MPa}$. Compared to sand mould casting $\mathrm{Al}-\mathrm{Si}-\mathrm{Cu}$ alloy, ${ }^{19}$ the tension strength increased by about $18.97 \%$. In general, at $750{ }^{\circ} \mathrm{C}$, the tension strength of the Al-Si-Cu alloys was the highest. Additionally, the tension strength of Al-Si-Cu alloy first decreases and then increases with the increase of the pulling rates at a given melting temperature. When the pulling rates increase from $100 \mu \mathrm{m} \cdot \mathrm{s}^{-1}$ to $300 \mu \mathrm{m} \cdot \mathrm{s}^{-1}$, the tension strength of the alloy increased about $23.6 \%$. So, the pulling rates have a significant influence on the tension strength. It can be seen from Figure $\mathbf{6 b}$ that the elongation at break increases with the increase of the pulling rates. When the pulling rate increases from $50 \mu \mathrm{m} \cdot \mathrm{s}^{-1}$ to $300 \mu \mathrm{m} \cdot \mathrm{s}^{-1}$ at a given melting temperature, the elongation at break of the Al-Si-Cu alloy increased about 33-50\%. With the increase of melting temperatures, the elongation at break of the alloy increased first and then decreased. Figure 6c shows the effect of different processing parameters on the microhardness of the Al-Si-Cu alloy, when the pulling rates increases from $50 \mu \mathrm{m} \cdot \mathrm{s}^{-1}$ to 300 $\mu \mathrm{m} \cdot \mathrm{s}^{-1}$ at a given melting temperature, the microhardness of the specimen increases. When the melting temperature was $750{ }^{\circ} \mathrm{C}$ and the pulling rate was $300 \mu \mathrm{m} \cdot \mathrm{s}^{-1}$, the maximum microhardness of the alloy was $102 \mathrm{HV}$.
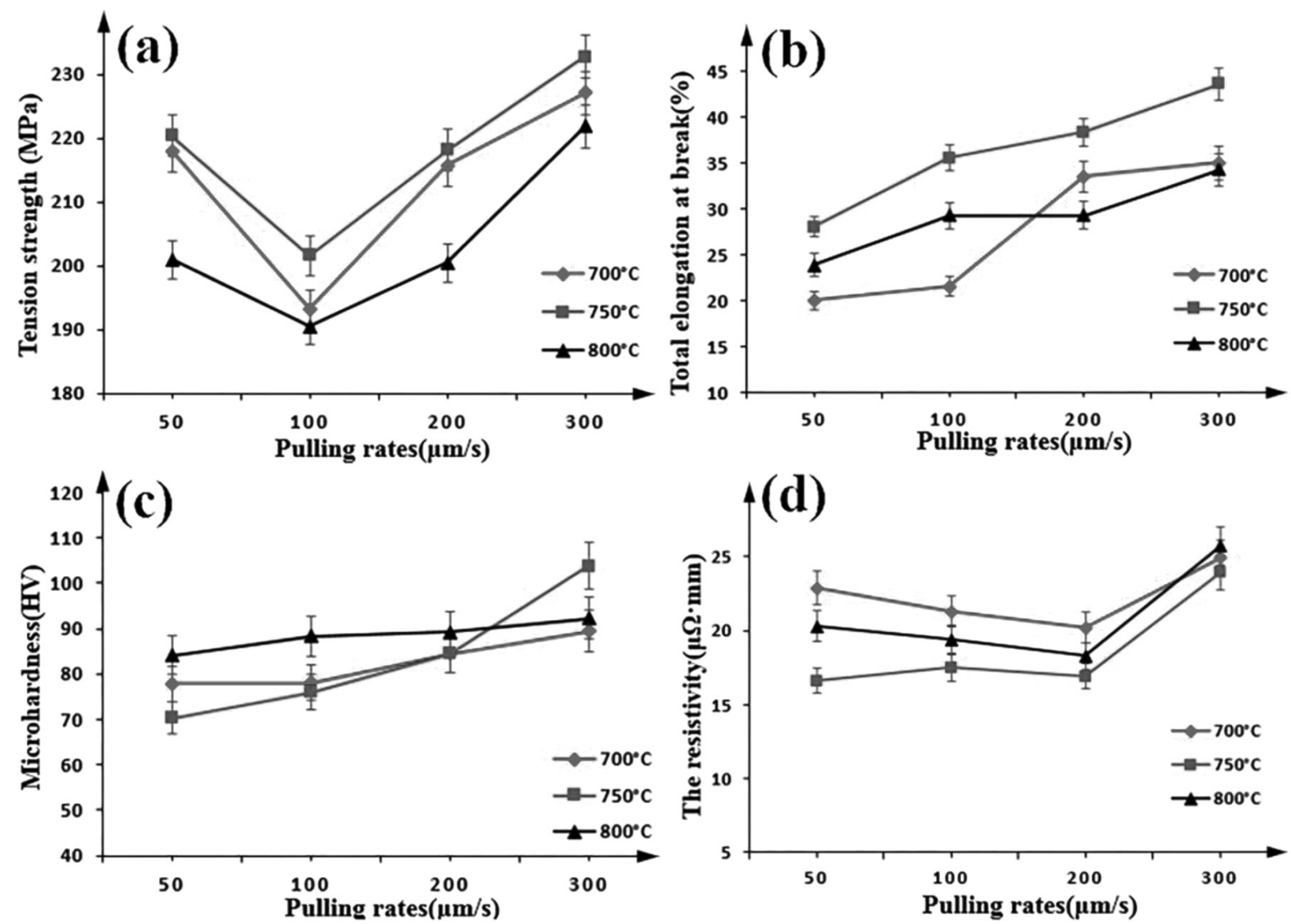

Figure 6: The effect of the melting temperatures and pulling rates on the mechanical properties and electrical properties of the Al-Si-Cu alloy 
Mechanical properties variation trend depends on the microstructure evolution in Figure 4. In Figure 4a, the dendrite of solid solution on $\alpha$-Al matrix is coarse and uneven. A coarse dendrite structure easily leads to stress concentration, which produces microcracks, and will accelerate the crack growth. Thus, the strength and microhardness of the alloy were reduced. In Figure $\mathbf{4 b}$, with the improvement of melting temperatures, the dendritic structure is refined, similar to A356 alloy proposed by $\mathrm{H}$. Liao. ${ }^{20}$ Dispersion strengthened granular eutectic not only increases the strength and plasticity of the alloy but also enhances the toughness of the Al-Si-Cu alloy. So, the mechanical properties of the alloy are better. In Figure $4 \mathbf{c}$, when the melting temperature continues to rise,
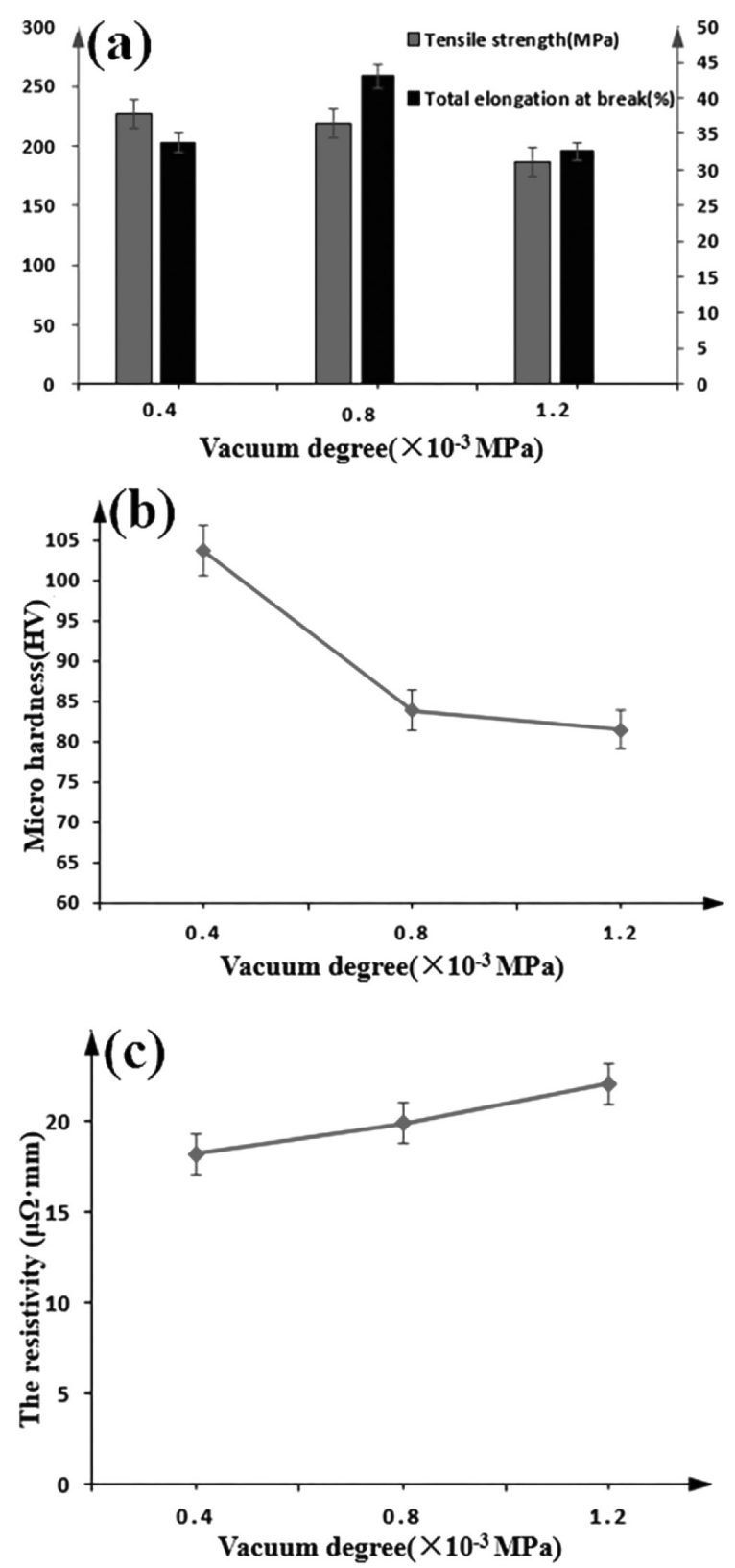

Figure 7: Effects of different vacuum degrees on the mechanical properties and electrical resistivity of the Al-Si-Cu alloy the results in granular eutectic aggregation, coarsening phenomenon, so reduces the strength and plasticity of the alloy.

Figure 6d shows the effects of melting temperatures and pulling rates on the electrical resistivity of the $\mathrm{Al}-\mathrm{Si}-\mathrm{Cu}$ alloy. At room temperature, pure aluminium had a resistivity of $2.94 \times 10^{2} \mu \Omega \cdot \mathrm{mm}$ and the pure silicon a resistivity of $2.52 \times 10^{5} \mu \Omega \cdot \mathrm{mm}$. The resistivity of pure copper was $1.85 \times 10^{2} \mu \Omega \cdot \mathrm{mm} .^{21}$ As can be seen from Figure $\mathbf{6 d}$, the resistivity of the novel $\mathrm{Al}-\mathrm{Si}-\mathrm{Cu}$ alloy was lower than that of any alloying element. When the pulling rate varies from $50 \mu \mathrm{m} \cdot \mathrm{s}^{-1}$ to $200 \mu \mathrm{m} \cdot \mathrm{s}^{-1}$, the resistivity gradually decreases. When the pulling rate exceeds $200 \mu \mathrm{m} \cdot \mathrm{s}^{-1}$, the resistivity sharply increases, the resistivity increased about $41.9 \%$. When the melting temperature was $750{ }^{\circ} \mathrm{C}$ and the pulling rate was $200 \mu \mathrm{m} \cdot \mathrm{s}^{-1}$, the average resistivity was about $18.7 \mu \Omega \cdot \mathrm{mm}$. It indicates that the conductivity was better at the melting temperatures of $750{ }^{\circ} \mathrm{C}$ and the pulling rate of $200 \mu \mathrm{m} \cdot \mathrm{s}^{-1}$.

As shown in Figure 4, when the melting temperature was $700{ }^{\circ} \mathrm{C}$, the solid solution on the $\alpha$-Al matrix has coarse dendrites, and there are many eutectics in the form of strip and plate and some discoid eutectic compounds. Most of these eutectic structures composed of silicon. ${ }^{22}$ Silicon is a semiconductor material, which has less conductivity than metal compounds at room temperature. Many primary silicon and eutectic silicon are disordered along with the growth direction, which against current delivery, so the resistivity is larger. When the melting temperature was $750{ }^{\circ} \mathrm{C}$, a large number of fine secondary granular eutectic and strengthening phases are dispersed in the $\alpha$-Al matrix, and the dendrite structure of the solid solution is further evenly refined, as shown in Figure 4b. The fine microstructure is beneficial to current delivery, so the resistivity is less. As the temperature of $800{ }^{\circ} \mathrm{C}$, too high temperature results in a large number of second phase short rod eutectic and a small amount of stripe and lamellar eutectic in the $\alpha$-Al matrix, as shown in Figure 4c. It also increases the current hindrance, which leads to an increase of the resistivity.

\subsection{Effects of vacuum degrees on the mechanical prop- erties and electrical resistivity of $\mathrm{Al}-\mathrm{Si}$-Cu alloy}

Figure 7 shows the effects of different vacuum degrees on the mechanical properties and electrical resistivity of Al-Si-Cu alloy. It can be seen from Figure 7a that the tension strength decreases with the increase of the degree of vacuum. When vacuum degree was $1.2 \times 10^{-3}$ $\mathrm{MPa}$, the tension strength of the alloy was the lowest, i.e., $191 \mathrm{MPa}$. When the vacuum degree was $0.4 \times 10^{-3}$ $\mathrm{MPa}$, the tension strength of the alloy reaches $226 \mathrm{MPa}$, which is about $19 \%$ higher than that of the alloy rod at the vacuum degree of $1.2 \times 10^{-3} \mathrm{MPa}$. Figure 7a shows that the elongation at break of the alloy rod first increases and then decreases with the increase of the degree of vacuum, and the maximum elongation at break 
was $43 \%$. Figure $7 \mathbf{b}$ shows that when the degree of vacuum increased from $0.8 \times 10^{-3} \mathrm{MPa}$ to $1.2 \times 10^{-3} \mathrm{MPa}$, the microhardness of the alloy decreased rarely. As the vacuum continues to decrease, the microhardness of the alloy rod increases rapidly, and the microhardness reaches $102 \mathrm{HV}$ at $0.4 \times 10^{-3} \mathrm{MPa}$. Compared with $1.2 \times$ $10^{-3} \mathrm{MPa}$, the microhardness of the alloy rod increases by about $30.7 \%$.

C. Lee et al. ${ }^{23}$ found that the tension properties of $\mathrm{Al}-\mathrm{Si}$ alloys depend on the microstructural characteristics. It can be seen from Figure 5 that the microstructure of the alloy rod was compact at $0.4 \times 10^{-3} \mathrm{MPa}$, and no cracks, shrinkage porosity and other defects were observed. With the decrease of vacuum degree, the shrinkage pinus, micro porosity, crack and other defects in the test rods were obviously decreased and accompanied by inclusions. The shrinkage pinus is caused by liquid shrinkage and volume shrinkage between solid and liquid lines during solidification of the alloy. The vacuum degree is too low, the original air in the cavity invades the liquid metal.

Figure 7c shows the effect of different vacuum degrees on the electrical resistivity of the Al-Si-Cu alloy. It can be seen that the resistivity of the test rods gradually decreases with the increases of the degree of vacuum, and the conductive ability becomes better. When the degree of vacuum was $0.4 \times 10^{-3} \mathrm{MPa}$, the lowest resistivity was $17.6 \mu \Omega \cdot \mathrm{mm}$. It can be seen from Figure 5 that when the vacuum degree is lower, the microstructure defects are much more, so that the resistivity of the alloy is higher.

\section{CONCLUSIONS}

1) With the increase of melting temperatures, the eutectic on the $\alpha$-Al matrix was refined from strip and plate to short rod and granular, and the number of second phases increased. When the melting temperature is too high, the second phase begins to coarsen and grow. At $750{ }^{\circ} \mathrm{C}$, the microstructure of $\mathrm{Al}-\mathrm{Si}-\mathrm{Cu}$ is the best and more uniform. Furthermore, the higher the vacuum degree of the alloy in solidification process, the less defects within the microstructure of the alloy.

2) With the increase of the pulling rates, the tension strength first decreases and then increases, the elongation at break and microhardness increase all the time, the resistivity first decreases and then increases. At the melting temperature of $750{ }^{\circ} \mathrm{C}$ and the pulling rate of $300 \mu \mathrm{m} \cdot \mathrm{s}^{-1}$, the mechanical properties of the alloy are the best, i.e., the tension strength is $232 \mathrm{MPa}$, and the microhardness is $102 \mathrm{HV}$, the maximum tension strength and microhardness increased about $21.4 \%$ and $47.1 \%$, respectively. At the melting temperature of $750{ }^{\circ} \mathrm{C}$ and the pulling rate of $200 \mu \mathrm{m} \cdot \mathrm{s}^{-1}$, the electrical properties of the $\mathrm{Al}-\mathrm{Si}-\mathrm{Cu}$ are the best, the minimum resistivity is 18.2 $\mu \Omega \cdot \mathrm{mm}$.
3) With the increase of the vacuum degrees, the tension strength and microhardness of the alloy gradually increase, and the electrical resistivity gradually decreases. The maximum tension strength and microhardness of the Al-Si-Cu alloy is $226 \mathrm{MPa}$ and $102 \mathrm{HV}$, respectively, at a vacuum degree of $0.4 \times 10^{-3} \mathrm{MPa}$. When the vacuum degree is $0.4 \times 10^{-3} \mathrm{MPa}$, the minimum electrical resistivity is the best, i.e., $17.6 \mu \mathrm{W} \cdot \mathrm{mm}$.

\section{Acknowledgements}

This project is funded by National Key Research and Development Program of China (Grant no. 2018YFB1307900), Key Research Program of Shanghai Science and Technology Commission (Grant no. 16030501200), National Natural Science Foundation of China (Grant No. 51805314) and Shanghai University of Engineering and Science (Grant No. E3-0903-17-01006 \& no. E3-0501-18-01002). The Robot Functional Materials Preparation Laboratory in Shanghai University of Engineering Science is also gratefully acknowledged.

\section{REFERENCES}

${ }^{1}$ P. Ebrahimzad, M. Ghasempar, M. Balali, Friction stir processing of aerospace aluminum alloy by addition of carbon nano tube, Transactions of the Indian Institute of Metals, 70 (2017) 1-13, doi:10.1007/s12666-017-1062-5

${ }^{2}$ H. Kaya, A. Aker, Effect of alloying elements and growth rates on microstructure and mechanical properties in the directionally solidified Al-Si-X alloys, Journal of Alloys \& Compounds, 694 (2017) 145-154, doi:10.1016/j.jallcom.2016.09.199

${ }^{3}$ S. K. Rathi, A. Sharma, M. D. Sabatino, Performance of Al-5Ti-1B master alloy after ball milling on minimizing hot tearing in Al-7Si-3Cu alloy, Transactions of the Indian Institute of Metals, 70 (2017) 827-831, doi:10.4028/www.scientific.net/KEM.737.27

${ }^{4}$ K. S. Alhawari, K. S. Omar, M. J. Ghazali, Microstructure evolution of semi-solid $\mathrm{Al}-\mathrm{Si}-\mathrm{Cu}$ alloys with different $\mathrm{Mg}$ contents, Chinese Journal of Nonferrous Metals, 27 (2017), doi:10.1016/S10036326(17)60169-9

${ }^{5}$ V. Maja, M. Jozef, B. Tonica, Z. Franc, Effect of Ce on $\alpha$ (Al) -A12 Cu eutectic morphology in Al-Si-Cu alloys, Chinese Journal of Nonferrous Metals, 1 (2014) 36-41, doi:10.1016/S10036326(14)63025-9

${ }^{6}$ A. Kolahdooz, S. A. Dehkordi, Effects of important parameters in the production of Al-A356 alloy by semi-solid forming process, Journal of Materials Research \& Technology, (2018), doi:10.1016/j.jmrt. 2017.11.005

${ }^{7}$ J. Hassan, M. H. Idris, A. Shayganpour, Significant processing parameters affecting the quality of $\mathrm{Al}-\mathrm{Si}-\mathrm{Cu}$ alloy thin-wall castings during EPC, Chinese Journal of Nonferrous Metals, 10 (2013) 2843-2851, doi:10.1016/S1003-6326(13)62805-8

${ }^{8}$ C. Y. Jin, S. X. Zhang, T. Sun, X. C. Quan, Effect of vacuum die casting technology on the appearance quality and mechanical properties of aluminum alloy die castings, Foundry, (2016), doi:10.3969/j.issn.1001-4977.2016.06.007

${ }^{9}$ Y. G. Wen, C. J. Cui, L. L. Tian, M. Yang, T. Xue, Progress and application of directional solidification technology, Materia News, 30 (2016) 116-120, doi:10.11896/j.issn.1005-023X.2016.03.022

${ }^{10}$ R. P. Mooney, S. Mcfadden, M. Rebow, D. J. Browne, A front tracking model for transient solidification of $\mathrm{Al}-7 \mathrm{wt} \% \mathrm{Si}$ in a Bridgman furnace, Transactions of the Indian Institute of Metals, 65 (2012) 527-530, doi:10.1007/s12666-012-0201-2 
${ }^{11}$ A. Dennstedt, L. Ratke, Microstructures of directionally solidified $\mathrm{Al}-\mathrm{Ag}-\mathrm{Cu}$ ternary eutectics, Transactions of the Indian Institute of Metals, 65 (2012) 777-782, doi:10.1007/s12666-012-0172-3

${ }^{12}$ Y. J. Sun, Q. Y. Li, X. Li, Y. J. Lin, Preparation of directional solidified pure aluminum test rod and its microstructure and properties, Journal of thermal processing, 42 (2013) 56-58, doi:10.14158/ j.cnki.1001-3814.2013.01.018

${ }^{13}$ G. Wan, B. L. Wu, H. S. Wang, Y. H. Zhao, Effect of current treatment on directional solidification of Al-Si alloy, Casting, 53 (2004) 1001-1004, doi:10.3321/j.issn:1001-4977.2004.12.012

${ }^{14}$ K. Q. Sun, Effect of melt overheating on the melt structure and directional solidification structure and properties of $\mathrm{Al}-\mathrm{Cu}$ alloy, Jiangsu University, (2005), doi:10.7666/d.y827168

${ }^{15}$ L. H. Cui, J. L. Pang, D. Y. Li, Effect of Cu content on directional solidification structure and primary dendritic spacing in $\mathrm{Al}-\mathrm{Cu}$ alloys, Hot Processing Technology, 40 (2011) 34-37, doi:10.3969/ j.issn.1001-3814.2011.15.011

${ }^{16}$ N. C. Si, N. J. Xu, S. H. Si, Y. D. Li, J. Shi, Effect of temperature gradient on primary dendritic spacing in directional solidification Al-4.5\% Cu alloy, Materials and Engineering, (2011) 75-79, doi:10.3969/j.issn.1001-4381.2011.04.016

${ }^{17}$ E. Samuel, B. Golbahar, A. M. Samuel, H. W. Doty, S. Valtierra, F. H. Samuel, Effect of grain refiner on the tensile and impact proper- ties of $\mathrm{Al}-\mathrm{Si}-\mathrm{Mg}$ cast alloys, Materials \& Design, 56 (2014) 468-479, doi:10.1016/j.matdes.2013.11.058

${ }^{18}$ T. He, L. Min, Y. M. Huo, H. J. Liu, X. J. Yi, Effect of temperatures and pulling rates on microstructure and mechanical properties of 6061 aluminum alloy in directional solidification, Mechanika, 24 (2018), doi:10.5755/j01.mech.24.1.19499

${ }^{19}$ X. W. Hu, F. R. Ai, H. Yan, Influences of pouring temperature and cooling rate on microstructure and mechanical properties of casting Al-Si-Cu aluminum alloy, Acta Metallurgica Sinica, 82 (2012) 2105-2110, doi:10.11890/1006-7191-124-272

${ }^{20}$ H. C. Liao, Y. Sun, G. X. Sun, Correlation between mechanical properties and amount of dendritic $\alpha$-Al phase in as-cast near-eutectic Al-11.6\% Si alloys modified with strontium, Materials Science \& Engineering A, 335 (2002) 62-66, doi:10.1016/S0921-5093(01) 01949-9

${ }^{21}$ H. M. Shi, H. Wang, H. Y. Li, J. Y. Lin, Formation mechanism and improvement of sidewall holes in $\mathrm{Al}-\mathrm{Cu}$ interconnection wires, Chinese Journal of Semiconductors, 34 (2009) 569-572, doi:10.3969/j.issn.1003-353x.2009.06.014

${ }^{22}$ Y. X. Jin, K. Ji, X. H. Fu, Al-P-Re-Sr composite metamorphic hypereutectic Al-Si alloy, Journal of Jiangsu University of Science and Technology, 37 (2008) 48-51, doi:10.3969/j.issn.10013814.2008.11.010 